CATALOGING A PHOTOGRAPHIC ALBUM AND PRESENTING IT ON THE WEB:

CHINESE PORTRAITS AND VIEWS

\author{
By \\ Yue Ma \\ BSc., Jilin University, China, 1989 \\ MBA, Xiamen University, China, 2000
}

\begin{abstract}
A thesis project
presented to Ryerson University \& George Eastman House

in partial fulfillment of the

requirements for the degree of

Master of Arts

in the Program of

Photographic Preservation and Collections Management
\end{abstract}

Toronto, Ontario, Canada \& Rochester, New York, USA, 2006

CYue Ma 2006 
UMI Number: EC53604

INFORMATION TO USERS

The quality of this reproduction is dependent upon the quality of the copy submitted. Broken or indistinct print, colored or poor quality illustrations and photographs, print bleed-through, substandard margins, and improper alignment can adversely affect reproduction.

In the unlikely event that the author did not send a complete manuscript and there are missing pages, these will be noted. Also, if unauthorized copyright material had to be removed, a note will indicate the deletion.

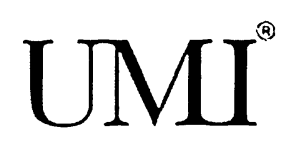

\section{UMI Microform EC53604 \\ Copyright 2009 by ProQuest LLC}

All rights reserved. This microform edition is protected against unauthorized copying under Title 17, United States Code.

ProQuest LLC

789 East Eisenhower Parkway

P.O. Box 1346

Ann Arbor, MI 48106-1346 


\section{Author's declaration}

I hereby declare that I am the sole author of this thesis project.

I authorize Ryerson University \& George Eastman House International Museum of Photography and Film to lend this thesis project to other institutions or individuals for the purpose of scholarly research.

Signature

I further authorize Ryerson University \& George Eastman House International Museum of Photography and Film to reproduce this thesis by photocopying or by other means, in total or in part, at the request of other institutions or individuals for the purpose of scholarly research.

Signature 


\title{
CATALOGING A PHOTOGRAPHIC ALBUM AND PRESENTING IT ON THE WEB: CHINESE PORTRAITS AND VIEWS
}

\author{
Master of Arts, 2006 \\ Yue Ma \\ Photographic Preservation and Collections Management \\ Ryerson University \& George Eastman House
}

\begin{abstract}
Based on the research of a Chinese photographic album in the George Eastman House (GEH) collections, my thesis project involves cataloging the album using The Museum System (TMS) and presenting it through eMuseum at the GEH website: http://www.emuseum.eastmanhouse.org. Accessed through the website, the album is titled, Chinese Portraits and Views under Collections.
\end{abstract}

This paper elucidates the three parts of this applied project: Research on the album, Cataloging in TMS, and Web presentation through eMuseum. In each section, I have included figures illustrating the specific methods and technologies adopted in the project, which can provide references for researchers doing similar projects in the future. Images published on the GEH website can also provide new opportunities for researchers to make further identifications on the image content, date, photographer, etc. 


\section{Acknowledgements}

My thesis project could not have been completed without the support of many individuals who offered their assistance during various phases of the research, practical realization, and writing.

I wish to express my appreciation to Alison Nordstrom, and Roger Bruce, who encouraged this project; to the assistance of Joe Struble, and Wataru Okada, who provided support in the use of GEH collection, and setting up TMS records; to my friend and classmate Taylor Whitney, who helped me to identify the handwriting in the album.

I also owe a debt of gratitude to David Wooters, and Laurie Soures, who supervised me during the process of cataloging, as well as in the techniques of TMS and eMuseum; and to Barbara Galasso, who offered her time and lab towards digitizing the album.

I wish particularly to thank my thesis advisor, Robert Burley, for instructing me in each phase of the project; to my husband and my son, for their continued support. 


\section{Table of Contents}

$\begin{array}{lr}\text { Introduction } & 1\end{array}$

0.1 Conceiving the project 1

0.2 Choosing the album 2

Chapter 1 Research on the album 4

1.1 Assigning filenames for images in the album 5

1.2 Research on the photographers 5

1.3 Research on the dates of the album 7

$\begin{array}{ll}\text { Chapter } 2 \text { Cataloging the album in TMS } & 9\end{array}$

2.1 Providing the lot information for the album 9

2.2 Transcribing the information from the album 10

2.3 Titling each image in the album 10

2.4 Other issues related to cataloging 13

Chapter 3 Presenting the album through eMuseum 14

3.1 Adjusting image quality 14

3.2 Linking images to TMS 14

3.3 Web-publishing through eMuseum 15

$\begin{array}{lr}\text { Chapter } 4 \text { Conclusion } & 17\end{array}$

$\begin{array}{lr}\text { Bibliography } & 19-20\end{array}$ 


\section{List of Figures}

\section{Introduction}

$\begin{array}{ll}\text { Fig. } 0-1 & 3\end{array}$

\section{Chapter 1 Research on the album}

Fig. 1-1

Fig. 1-2 6

Fig. 1-3

$\begin{array}{ll}\text { Fig. 1-4 } & 7\end{array}$

Chapter 2 Cataloging the album in TMS

Fig. 2-1 9

Fig. 2-2 11

Fig. 2-3 12

Fig. 2-4

Chapter 3 Presenting the album through eMuseum

$\begin{array}{ll}\text { Fig. 3-1 } & 14\end{array}$

Fig. 3-2 15

Fig. 3-3 16

Fig. 3-4 16 


\section{Introduction}

This project was undertaken as a thesis project in the Photographic Preservation and Collections Management (PPCM) graduate program, taught jointly at Ryerson University in Toronto, Canada, and George Eastman House in Rochester, New York. My thesis advisor for this project was Robert Burley, Assistant Professor, PPCM Program Director at The School of Image Arts, Ryerson University. My professional project involves researching a photographic album, cataloguing it in a database and presenting it in a website.

\subsection{Conceiving the project}

When I first found the PPCM program, and decided to apply for it, I knew that I wanted to specialize in the recently developed area of digital photographic collections. During my two years of study, especially in the $2^{\text {nd }}$ year at GEH, I was very interested in gaining knowledge and working experience of The Museum System (TMS). After consulting with Alison Nordstrom, Roger Bruce, Laurie Soures and my thesis advisor Robert Burley, I conceived and proposed this project, working with the GEH collection using both TMS and eMuseum.

TMS and eMuseum are products of Gallery Systems, a company that provides software and services for museums, foundations, collectors and visual resource libraries throughout the world. ${ }^{1}$

TMS is a collections management system used to manage collections, content and media. Features include object cataloguing, registration, media management, and coordination of exhibitions, loans and shipping. ${ }^{2}$

\footnotetext{
${ }^{1}$ Gallery Systems. "Company". <http://www,gallerysystems,com/company/company.html>(6 July 2006)

${ }^{2}$ Gallery Systems. The Museum System User's Guide.
} 
eMuseum is a web-based, database-driven publishing system that can be used as a tool to publish the data managed in TMS on an intranet or internet site. When integrated with collections data, eMuseum enables organizations to publish collections information online. ${ }^{3}$

\subsection{Choosing the album}

I was born and grew up in China. In the GEH collection, there are half a dozen $19^{\text {th }}$ century albums that contain photographs of China and Chinese people. I am very interested in the subjects of these photographs, and was familiar with many of them. I looked through most of them, and chose one titled Chinese Portraits and Views, accession number 1979:0027:0001-0078, which includes landscapes and portraits made in various places.

This album is one of the four albums of the Far East that GEH bought from Fred S. Lightfoot on Sep. 17, 1959 for \$20. Fred Lightfoot had a close relationship with GEH as a seller between 1948 and 1966. He communicated with Beaumount Newhall, director of GEH at the time, by mail, describing the photographs of the Far East he purchased that might be acquired by GEH to enrich its collections. ${ }^{4}$

The images in this album were originally purchased by a wealthy tourist in the years 1871-73, and bound in a large album ${ }^{5}$. All the images are albumen prints, and some of them were carefully hand-coloured at the time they were created. Many are $8 \times 10$ inches and some are multiple panels (including 5 panoramas), showing portraits and views in locations throughout Mainland China, such as Beijing, Shanghai, Suzhou, Ningbo, Hankou, and Guangzhou, as well as a few in Hong Kong, Macau, and Singapore.

I chose this particular album because it covered a wide range of Chinese subjects and also because I noticed that the traveling route and date noted in the album were similar to the

\footnotetext{
${ }^{3}$ Gallery Systems. eMuseum3.5 Manual.

${ }^{4}$ Museum Registration Materials for Fred S. Lightfoot.

${ }^{5}$ Ibid.
} 
itinerary of the British photographer John Thomson, who photographed in China during this same time period. The information related to John Thomson led to the album being attributed to Thomson when it was first acquired by GEH.

John Thomson was born in Edinburgh in 1837, but as a young photographer of architecture, he was little known before he set out on his first foreign trip in the 1860 's. ${ }^{6}$ Thomson, who arrived in China in 1868, and left in 1872, told an interesting story about China and its people at that time. During these five years, he traveled approximately five thousand miles in China, and his trip can be traced from southern Hong Kong and Canton (Guangzhou) in 1868-1870, through the island of Formosa (Taiwan) and inland Fujian in 1870-1871, to the Northern Peking and Shanghai in 1871-1872. Thomson first decided to leave England for the Far East in 1862 at the age of twenty-five, however he began his travels in Singapore and Siam (Thailand) before making his way to China six years later. ${ }^{7}$ Fig. $0-1^{8}$ shows a map of his route in Far East.

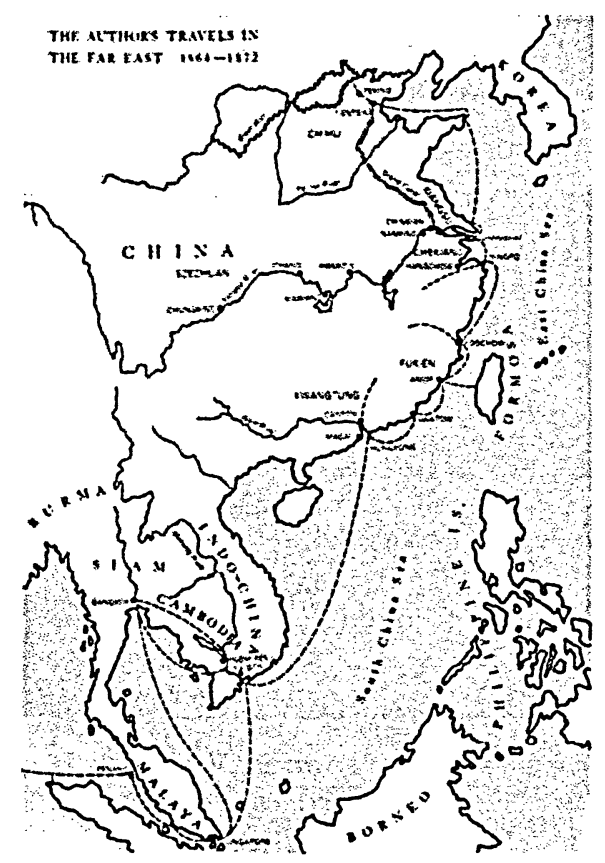

Fig. 0-1

\footnotetext{
${ }^{6}$ Cameron, Nigel. The Face of China as Seen by Photographers \& Travelers, 1860-1912, 152. Millerton: Aperture, 1978.

${ }^{7}$ White, Stephen. John Thomson: A Window to the Orient, 9-29. New York: Thames and Hudson, 1986.

${ }^{8}$ Thomson, John. China: the Land and Its People, 10. Hong Kong: John Warner Publications, 1977.
} 


\section{Chapter 1 Research on the album}

I started this project early in the first term (Fall2005) at GEH. After I settled on my project topic, I immediately contacted Barbara Galasso, the museum photographer to inquire about having the album transferred to a digital platform. She completed the process of digitizing the album in late December, 2005. Once this process was complete, I was able to produce digital prints of the album and then was able to create a reference copy, see Fig. 1-1. Once this reference copy was complete I was able to start my research on the album early in the second term (Winter2006).

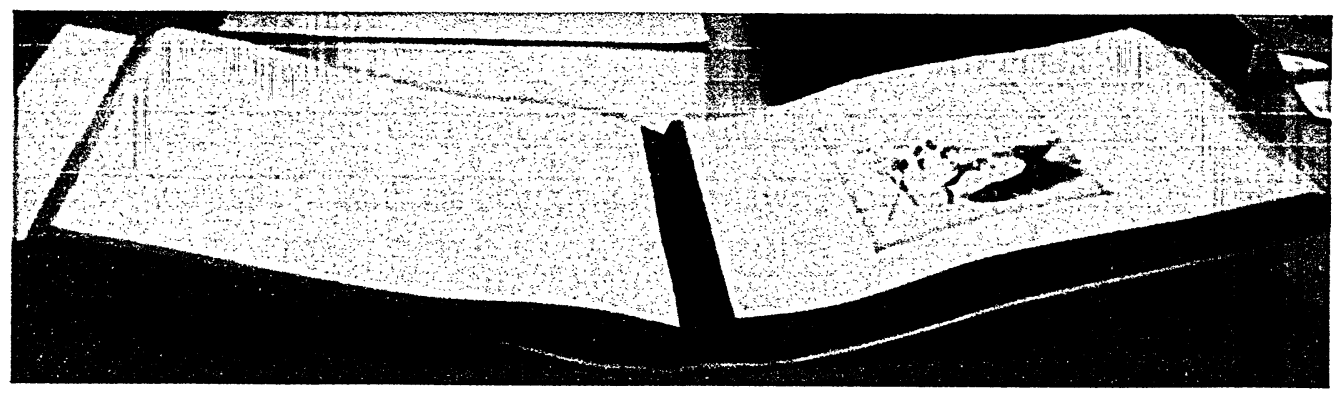

Original Album

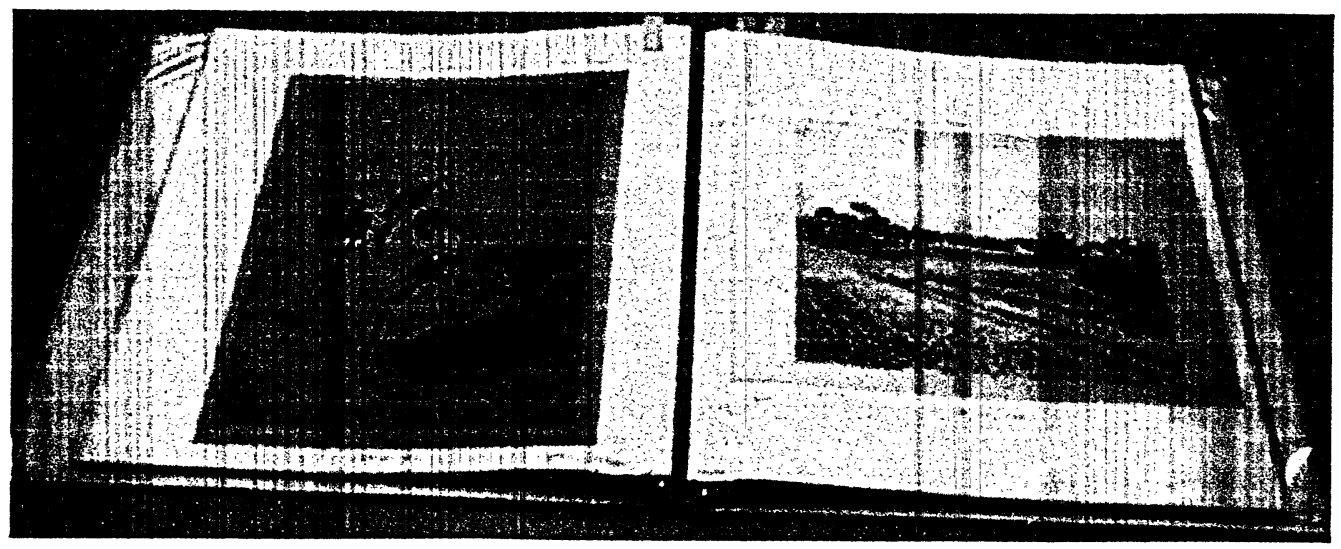

Reference Copy

Fig. 1-1

In order to catalog this album in TMS and publish it on the GEH website through eMuseum, some preliminary research was required. 


\subsection{Assigning filenames for images in the album}

The digital file for each image is given a file name corresponding to its accession number in the album. For example, the accession number for the first image in the album is 1979:0027:0001, and the corresponding digital image file name should be named 197900270001.jpg or 197900270001.tif (.jpg or .tif depends on original digital file format. In this album, all images were saved as .jpg format, except the five panoramas which were saved in tif format). The accession number for the entire album 1979:0027:0001-0073 was used to create the corresponding digital image file name, 197900270001-0073.jpg, for the album cover. When I finished this job, I noticed that the number of the images in this album was not 78 (the original count when it was first registered in GEH collections), but 73. I concluded that this error was the result of each of the five two plate panoramas being counted as two photographs rather than one.

\subsection{Research on the photographers}

As I mentioned above, this album was originally attributed to John Thomson. However, when I looked through John Thomson's published photographs, such as four volumes of China and Its People in Early Photographs, 1982, China: The Land and Its People, 1977, and Stephen White's John Thomson: A Window to the Orient, 1986, I was unable to find any of the Thomson images that matched the photographs in the album.

It is interesting to note that the route, the places and the time period of this album are very similar to those associated with John Thomson's visit to China (1868-72). If you compare images in this album to John Thomson's published images (see Fig. $1-2^{9}$ ), it is easy to imagine that the images in this album might have been created by John Thomson at the same time, and sold in the markets, but not included in his publications. Therefore, one can easily understand why this album was originally attributed to John Thomson.

\footnotetext{
${ }^{9}$ White, John Thomson: A Window to the Orient, 138.
} 

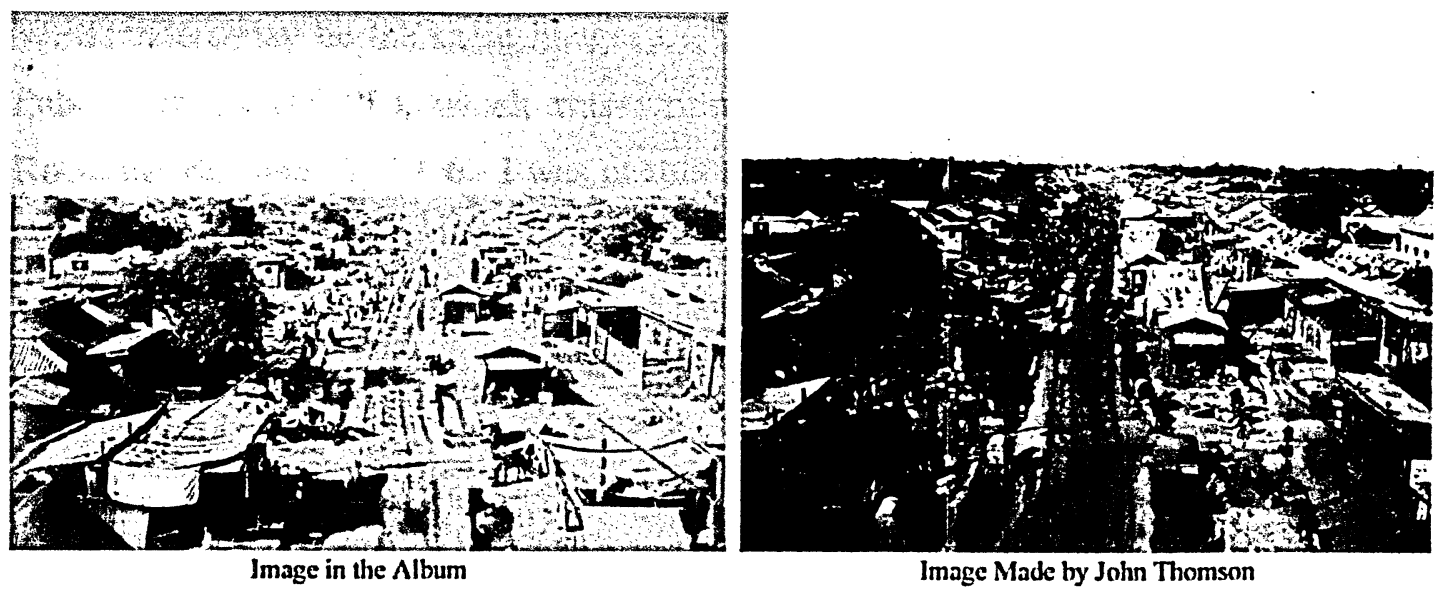

Image Made by John Thomson

Fig. 1-2

When I extended my research to other books, I found four images in Nigel Cameron's The Face of China as Seen by Photographers \& Travelers, 1860-1912 that were identical to images in the GEH album. See Fig. 1-3. However, only one (upper-right) was attributed to John Thomson in Cameron's book, and the other three were made by unknown photographers.

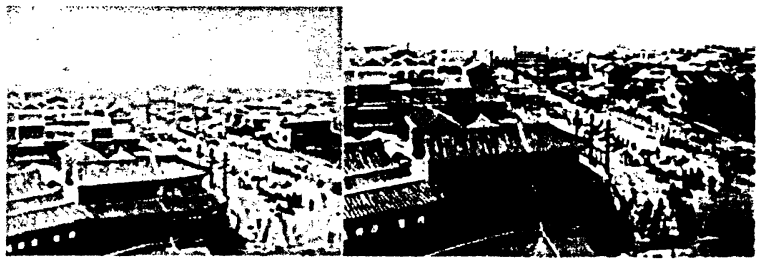

1979:0027:0013 in the Album

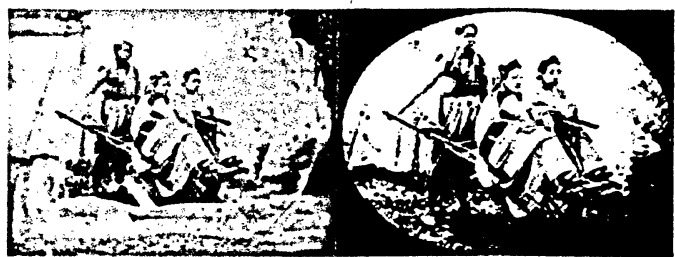

1979:0027:0033 in the Album
Published lmage

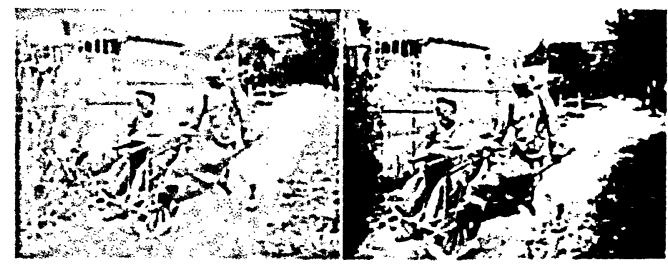

1979:0027:0030 in the Album

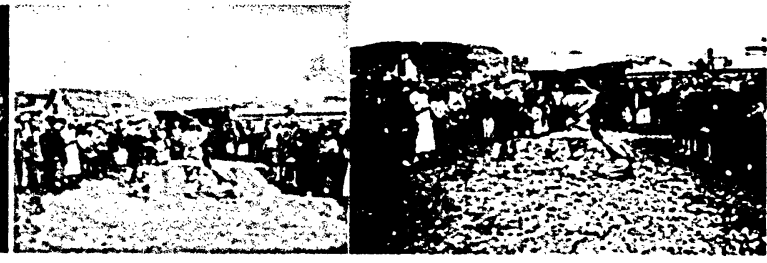

1979:0027:004I in the Album

Published Image

Fig. 1-3 
Inside the album is a note: "79: $027: 1-78 /$ contains photos of Shanghai possibly made by W. Saunders/may be the same images by Saunders in the collection of the New York Public Library"(NYPL), which was written by a researcher named Robert Woo in Rochester on June 27, 1996. I was unable to find any work by Saunders reproduced in books, but when I searched on NYPL's website, I found one image made by Saunders on NYPL Digital Gallery that was the same as the lower-right image in Fig. 1-3, see Fig. 1$4^{10}$.

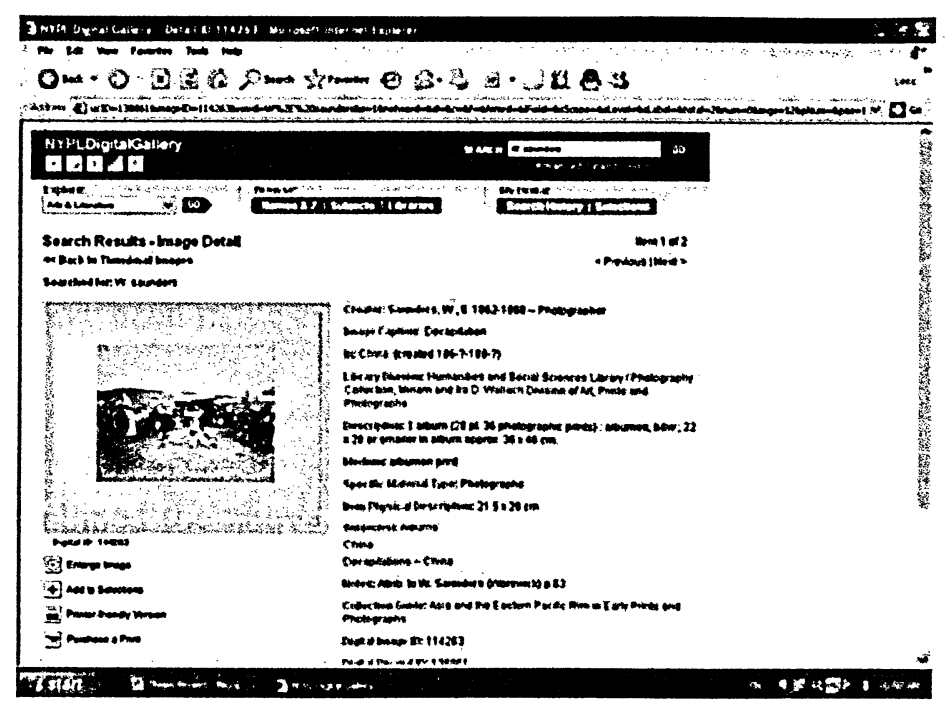

Fig.1-4

Based on my research on the photographers represented in this album, I concluded that 1979:0027:0030 can be attributed to John Thomson, and 1979:0027:0041 can be attributed to W. Saunders. All other images in this album should be considered to have been made by unknown photographers.

\subsection{Research on the dates of the album}

\footnotetext{
${ }^{10}$ New York Public Library. "Detail ID 114263". NYPL Digital Gallery. $<$ http://digitalgallery.nypl.org/nypldigital/dgkeysearchdetail.cfm?trg=1\&strucID=138861\&imageID=114263\&word=W

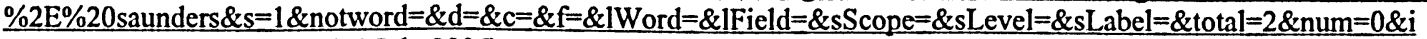
mgs=12\&pNum=\&pos $=1>(14$ July 2006)
} 
In the letter that Fred S. Lightfoot wrote to Beaumont Newhall on September 6, 1959, he said that "...all purchased by a wealthy tourist in the years 1871-73", which suggests that the images in the album were created before the years 1871-73.

However, when I reviewed the images in the album, I discovered that there are two prints with watermarks, which read "1874 B.F.K. RIVES". I consulted GEH Assistant Archivist Joe Struble, and learned that B.F.K. RIVES was a paper manufactory's name. After researching this discovery, I found that B.F.K. RIVES currently refers to a kind of paper product of Island Blue Print Co. Ltd. - an excellent paper for all printmaking techniques, which is $100 \%$ rag buffered acid free with four deckle edges and vellum surface. ${ }^{11}$ Using the watermarks as a date reference, the year 1874 allows me to conclude that the prints were made sometime after the paper was made, which was in 1874 . While the images may have been made earlier, this evidence suggests a later date for the album than 1871-73.

In addition, I combined the above analysis with the published information on the four images that I found to be the same in both the album and in Nigel Cameron's The Face of China as Seen by Photographers \& Travelers, 1860-1912. I then dated the album ca. 1872, indicating a date between 1865 and 1875.

\footnotetext{
"Island Blue Print. "BFK Rives Paper". IslandBlue Art Supplies Save Your Best Ideas for Us.

$<$ http://www.islandblue.com/catalogue.cfm?main id=3\&sub id=14\&product id=873> (9 July 2006)
} 


\section{Chapter 2 Cataloging the album in TMS}

The need of an organized worksheet became very obvious when I realized there was so much information to deal with! ${ }^{12}$ To begin the cataloguing process for the album in TMS, I chose to use the George Eastman House-Photography Collection Cataloguing Form as my worksheet, and then put all forms for the images together to make a cataloging form book for the album. Fig. 2-1 shows the format of the cataloging form.
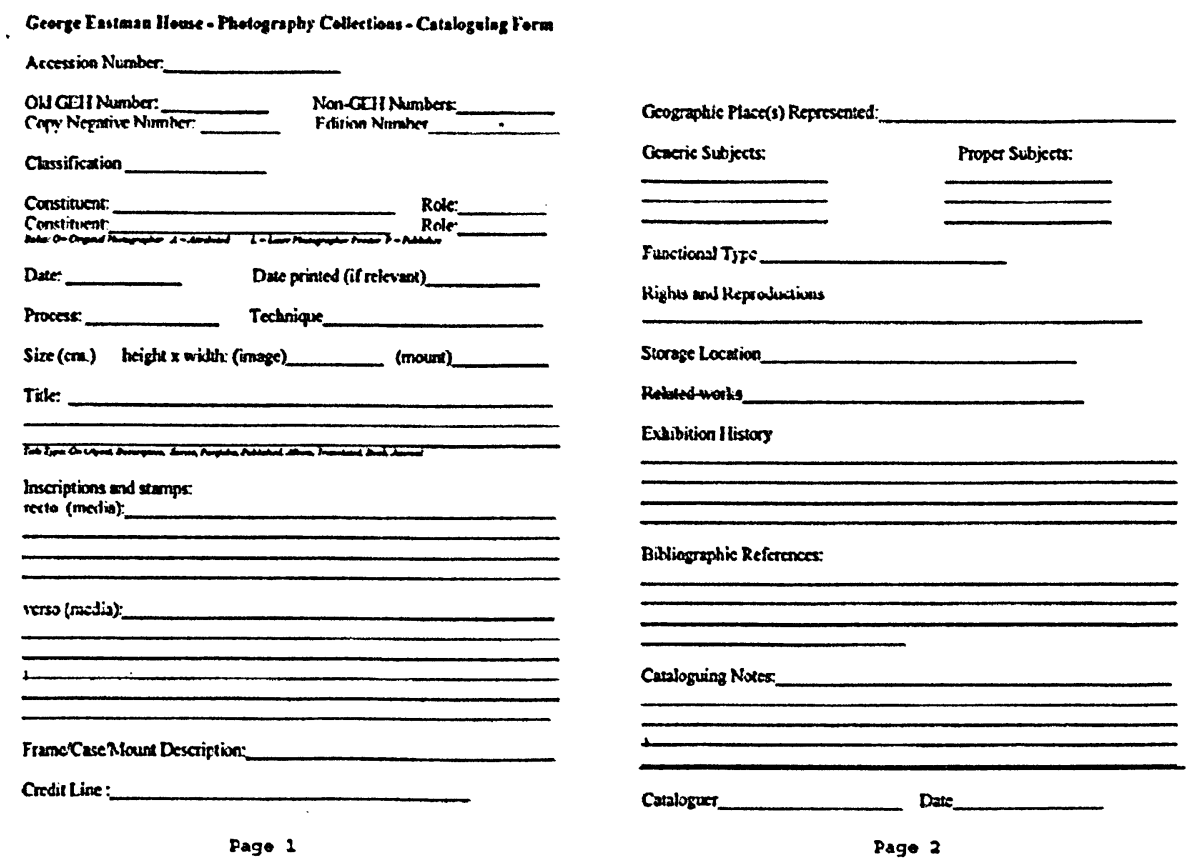

Fig. 2-1

\subsection{Providing the lot information for the album}

Before splitting the lot record to seventy-three individual item records, the registrar Wataru Okada asked me to provide the lot information for the album. Then, when he

\footnotetext{
${ }^{12}$ Frisch-Ripley, Karen. Unlocking the Secrets in old photographs, 45. Salt Lake: Ancestry, 1991.
} 
split the lot record, some information could be repeated automatically by the system. This way I saved data entry time and avoided typing mistakes.

These fields include:

Constituent: Original Photographer: Unidentified Seller/Vendor: Fred S. Lightfoot, 1920-1992

Medium: Albumen Print

Description: Chinese Portraits and Views, CA 1872

Storage Location: 1979:0027:0001-0073: George Eastman House, Photo Collection, Album

I was allowed to modify a specific object record if it had different information for these common fields. For instance, I changed the Constituent for 1979:0027:0030 from "Unidentified" to "Photograph attributed to John Thomson, 1837-1921".

\subsection{Transcribing the information from the album}

As I mentioned above, two images have watermarks "1874 B.F.K. RIVES"; some prints also have reversed numbers from the numbers written onto the negatives. The person who made the album often wrote the image description on the back of the image, or on the album mount. The pencil inscriptions often show through the print, or are partially covered by the print. Almost every image has a title and page number written in pencil near the top of the album mount. All of this information was transcribed during the cataloging procedure. For example:

Mount recto (pencil): Malley Woman

King Coolar Singapore

119

(pencil inscription shows through print): Malley Woman

(pencil inscription partially covered by print): King Coolar Singapore

Print recto (reverse number from negative): 258

119

\subsection{Titling each image in the album}


In TMS, you choose one or more title types for each image: "title on object", "published title", "descriptive title", "translated title", and so on.

As I said before, almost every image in this album has a title written in pencil near the top of the mount. In other words, almost every image in this album has a title on the object. However, it is very difficult to read this faint and almost illegible handwriting. Fig. 2-2 shows an example of title on 1979:0027:0024, "Carving on the Base of Pagoda Pekin Illustrating life of Buddha".

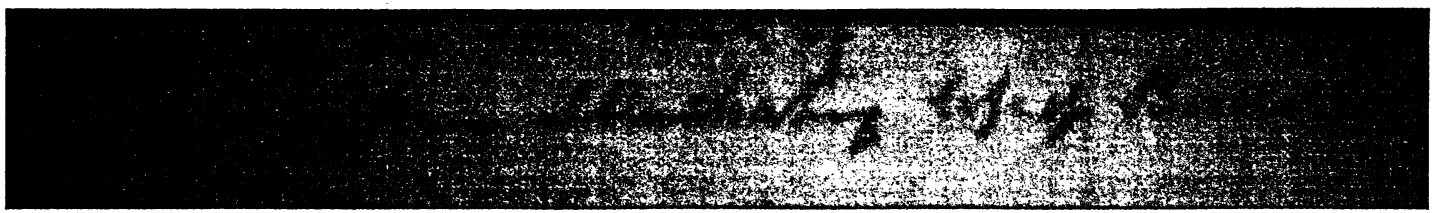

Fig. 2-2

Some inscriptions were even more difficult. In the worst cases, the writing on some images was written at the edge of the mount, and you can only see half letters. My classmate Taylor Whitney spent a whole morning volunteering as a second reader; Joe Struble spent additional time working on the hardest parts, employing his rich experience; I also combined my knowledge of Chinese culture and made the determinations for some images, like "Wan-Show-Hall Palace", and "Wang-Ho-Low Pagoda" etc.

In addition, the four published images have their own published titles, while few images in this album had no title on the object. I gave descriptive titles to the ones with no titles, based on my research, knowledge and experience.

Fig. 2-3 is an example. There is no title on 1979:0027:0029, but when I researched John Thomson's photographs, I found an image he made of the same place. 


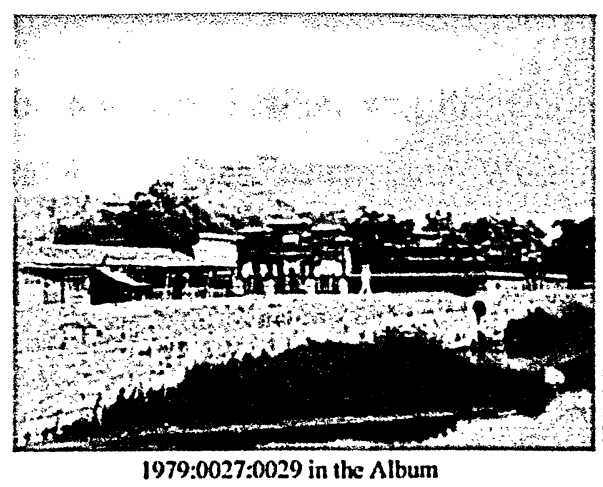

1979:0027:0029 in the Album

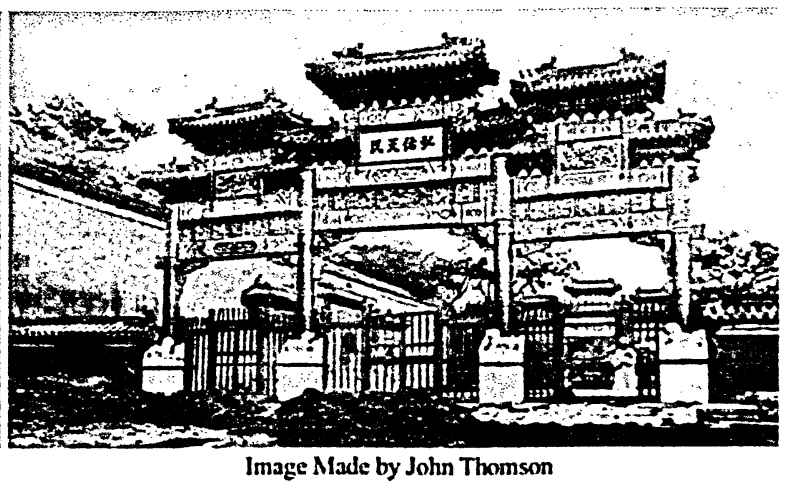

Fig. 2-3

John Thomson published this photograph in "China and Its People in Early Photographs" Vol. IV, as Plate XIV. He titled it "A Pekinese Pai-Lau [sic]", which was also called a Chinese honorary portal that was erected at the gate of Ta-ka-tien [sic] temple which the Emperor visited when he prayed for rain. ${ }^{13}$

1979:0027:0031 is another image in the album with no title (see Fig. 2-4). However, it is very interesting to note that the Chinese words “弘侑天民(Emperor blesses the common people)" on the structures in 1979:0027:0029 and the words “孔绥星神(Confucius stabilizes the empery)" in 1979:0027:0031 compose a rhyming couplet. After researching them, I found that these are two of the three "Pai-Lau"s (Pai-lou) of "Ta-katien" (Da-gao-xuan-dian) temple, the Eastern Pai-lou and Western Pai-lou, which were built in 1542. A third Pai-lou, the Southern Pai-lou, was built in 1600 when the Da-gaoxuan-dian temple was rebuilt after it was ruined in a fire in $1548 .{ }^{14}$

The Eastern Pai-lou, inscribed “孔绥泉神(Confucius stabilizes the empery)"on the front is inscribed “尖天明镜 (Ancestor makes the appreciation)" on the back; the Western Pai-lou, inscribed “弘倠天民 (Emperor blesses the common people)" on the front bears the inscription “太极们林 (Taoism has a fairyland)" on the back. ${ }^{15}$

\footnotetext{
${ }^{13}$ Thomson, John. China and Its People in Early Photographs, an Unabridged Reprint of the Classic 1873/1874 Work, Vol. IV, Plate XIV, NO. 38. New York: Dover Publications, Inc., 1982.

${ }^{14}$ Beijing Xi Cheng Qu Archives. "Da Gao Xuan Dian Temple". Xi Cheng Qu Archives online. $\langle$ http://xchda.bjma.org.cn/xcbk/gims-simiao- $1 . \mathrm{htm}>(15 \mathrm{July} 2006$ )

${ }^{15}$ Xin Hua Net. "Beijing Pai-lou Titles". Xin Hua Net Beijing News. <http://www.bj.xinhuanet.com/bjpd_sdwm/200607/05/content_6557322.htm>(15 July 2006)
} 
The Southern Pai-lou was dismantled in 1917 because the structure was leaning and unstable. The Eastern and Western ones were removed in 1954 because of road expansion, and now stand in the Central Party School in Beijing. ${ }^{16}$

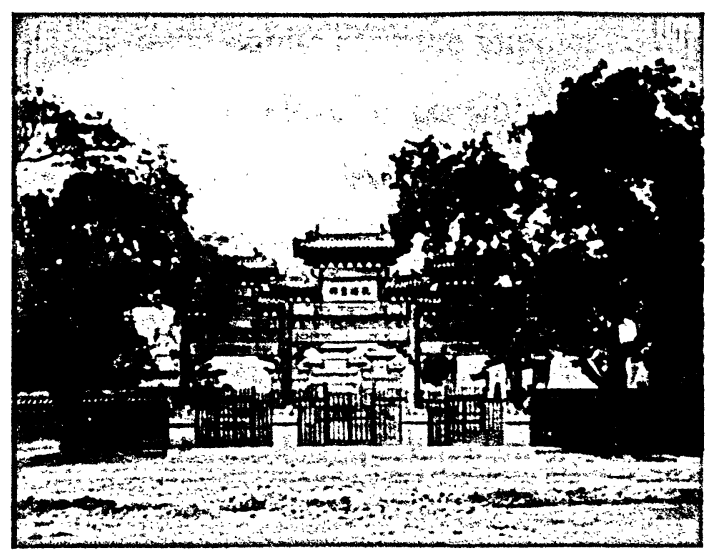

Fig. 2-4

This research led me to assign a descriptive title "An Honorary Portal - the Western PaiLau of Ta-ka-tien temple" for 1979:0027:0029, and "An Honorary Portal - the Eastern Pai-Lau of Ta-ka-tien temple" as the descriptive title for 1979:0027:0031.

\subsection{Other issues related to cataloging}

Certainly, there were also other things that had to be done to complete the cataloging of the album in TMS before it could be presented on the web. Tasks such as measuring the dimensions of each image, making descriptions or cataloging notes for specific images if necessary, creating bibliography information for the four published images, and selecting "Generic Subject" and "Geography Information" for each image from the GEH Terms. I completed this work before continuing to the next step in the process.

\footnotetext{
${ }^{16}$ Old Beijing net. "Pai-lou". Old Beijing Civilisation.

$<$ http://www.obj.org.cn/article/Article Show.asp?ArticleID=7186 $>$ (15 July 2006)
} 


\section{Chapter 3 Presenting the album through eMuseum}

\subsection{Adjusting image quality}

In order to show clear images to the public over the internet, and to insure that the digital reproductions in TMS were made as close as possible to the original photograph, the image quality was adjusted to two different levels using Photoshop software. The one for use in TMS was adjusted to be very close to the original image in the album, and the other one was adjusted for best web quality to be presented online through eMuseum. Fig. 3-1 is the example for 1979:0027:0025. The left image is the original digitized image, the middle one is the image for TMS, and the right one is the web-published image.

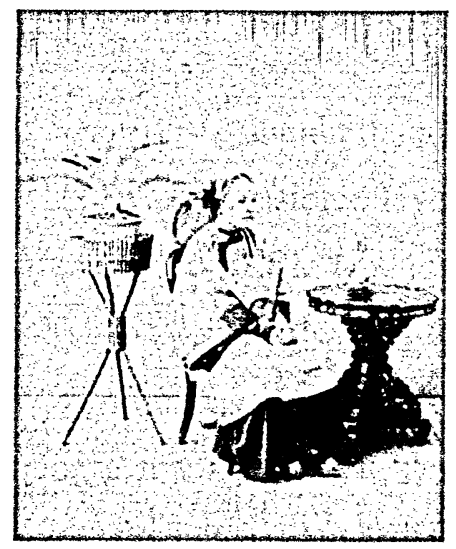

Original Digital File

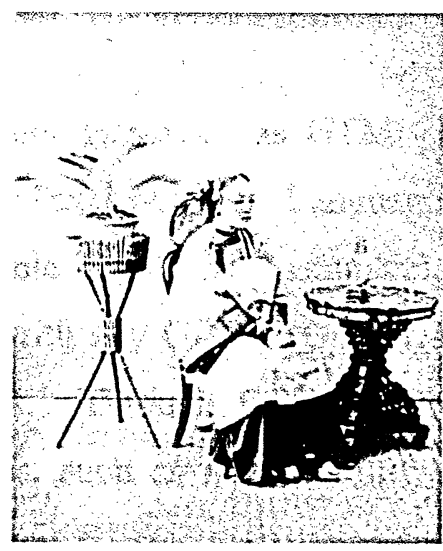

Adjusted for TMIS

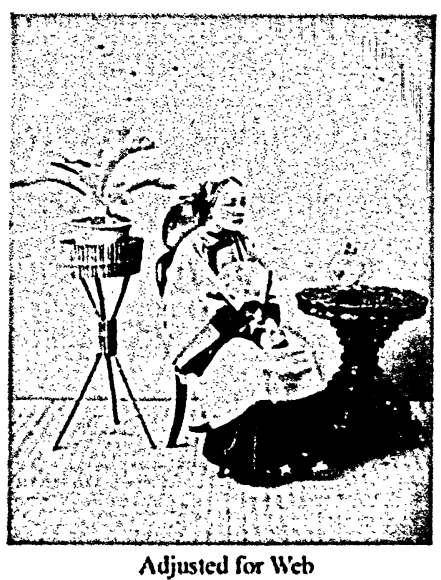

Adjusted for Web

Fig. 3-1

\subsection{Linking images to TMS}

After adjusting the image quality, I linked the images to TMS, setting the one for TMS to be "primary display" and "public access", and the one for Web to be "public access" with the sentence "This image has been digitally enhanced for web display." in the public 
caption of the media record in TMS. Fig 3-2 shows the front card of an image record in TMS after image linking.

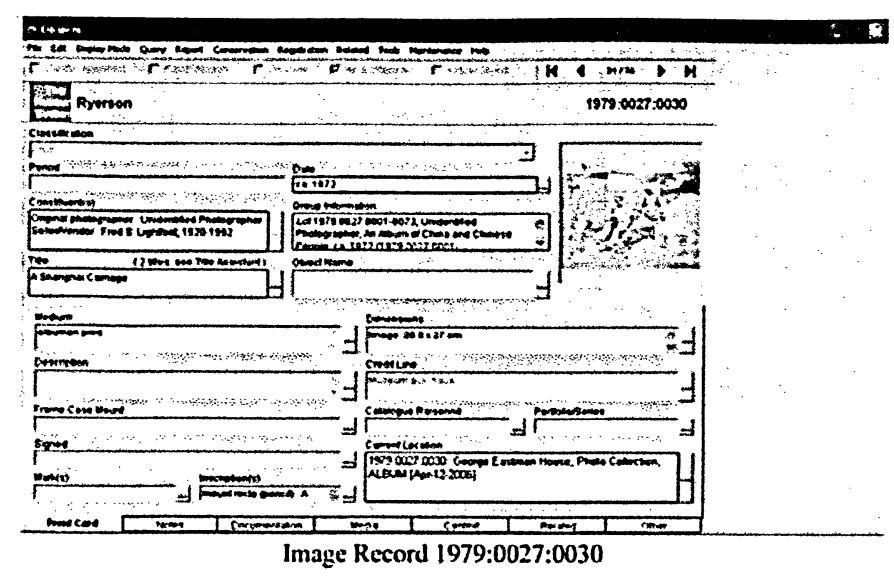

Fig. 3-2

\subsection{Web-publishing through eMuseum}

eMuseum uses standard technologies such as HTML (HyperText Markup Language) IXHTML (Extensible HyperText Markup Language), XML (Extensible Markup Language), or XSL (Extensible Stylesheet Language). It is a database-independent application and will operate with any ODBC (Open Database Connectivity) compliant database management system. Through ODBC, eMuseum works with a range of database management systems, such as Microsoft SQL (Structured Query Language) Server which is used at GEH.

For my project, after linking images to TMS, I first made an object package in TMS, wrote HTML code to define the album description for Web-presenting, and set "Global" and "Public Access" in "Package Info". Fig. 3-3 illustrates the object package.

eMuseum is delivered with standard templates that provide a dynamic web interface for searching and displaying collections information. Working with Microsoft SQL Server, the album is presented on the GEH website in the specific way by eMuseum, and the album can be searched and displayed as shown in Fig. 3-4. 


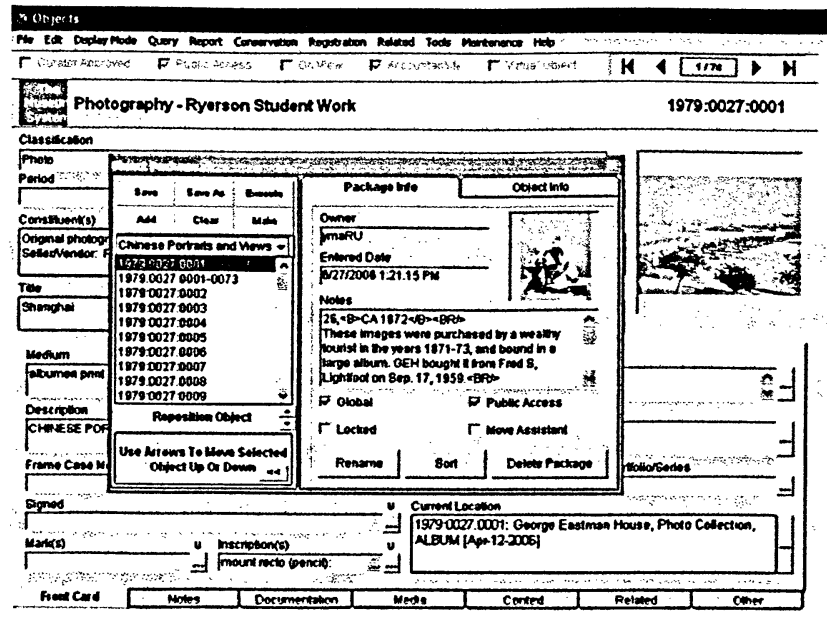

Fig. 3-3

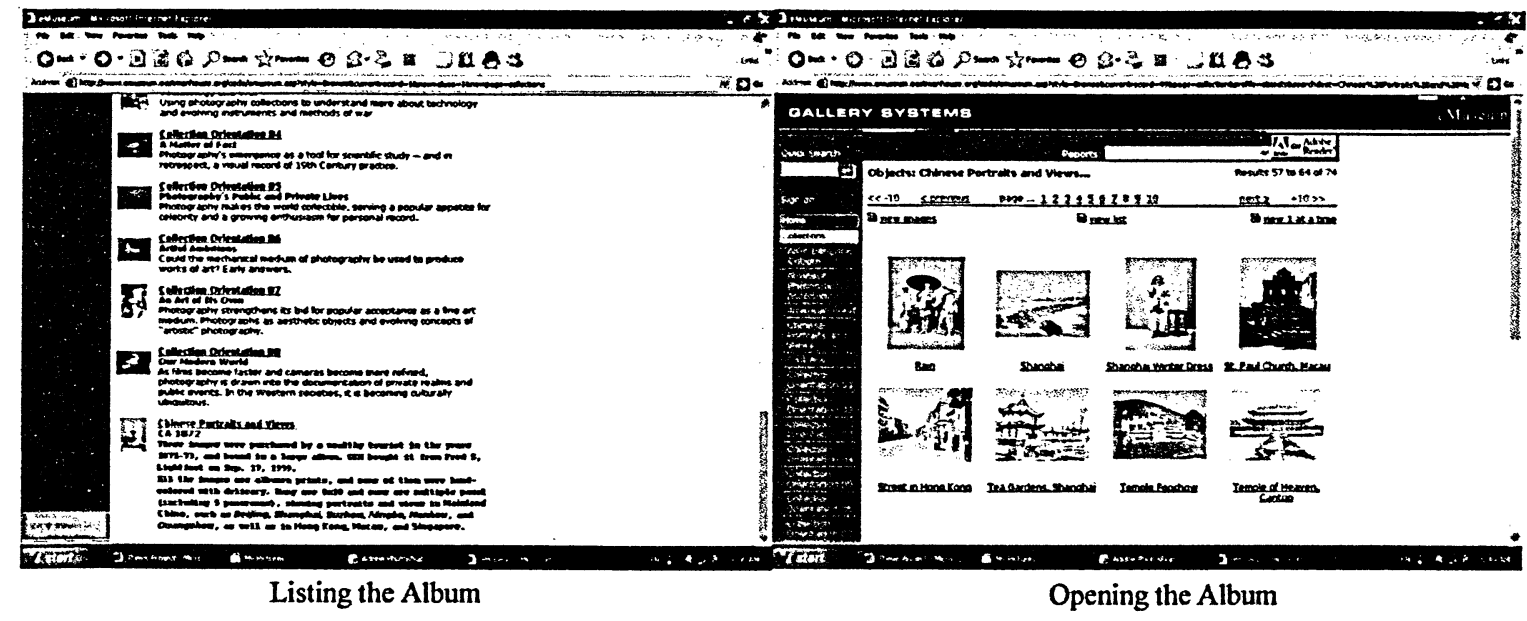

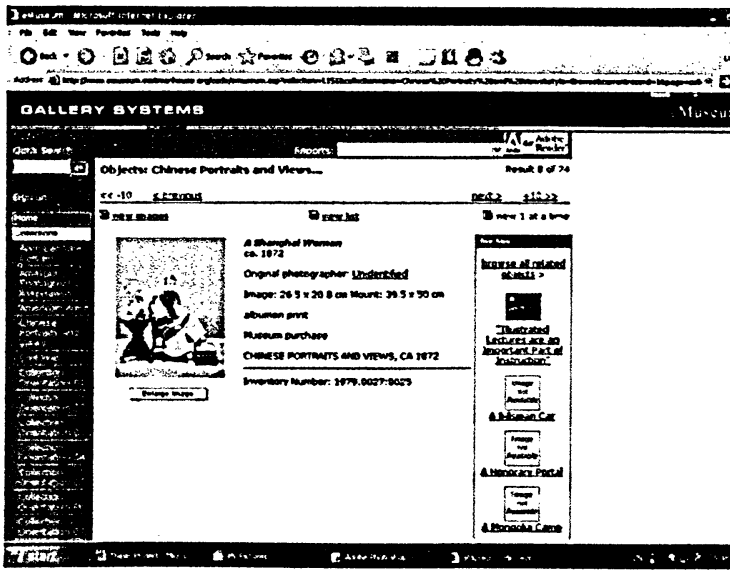

Opening an Image
7.
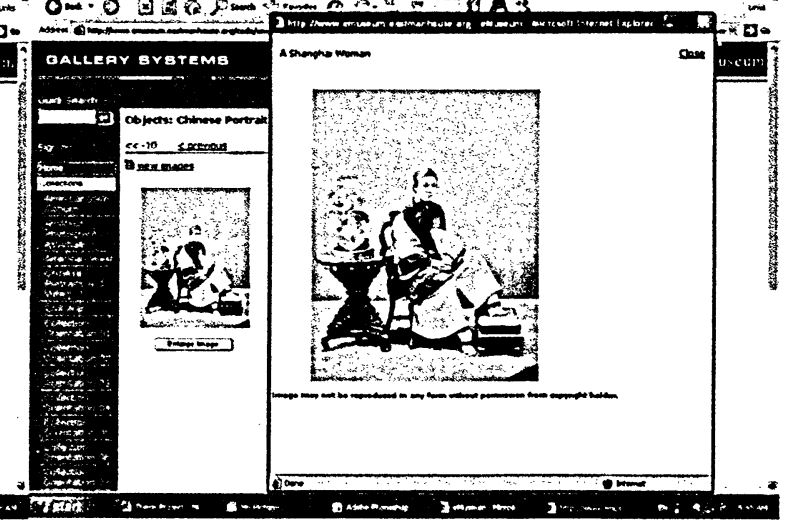

Enlarging an Image

Fig. 3-4 


\section{Chapter 4 Conclusion}

After photography was invented in 1839 , scenic views in China were first created by visiting Europeans who brought with them, in the wake of the rebellions and wars that opened China to Western imperialism, equipment, fortitude, and traditional Western concepts of pictorial organization. ${ }^{17}$ Photographers from the West began to make portraits there during the $1860 \mathrm{~s}^{18}$ Photographic portrait studios appeared in Hong Kong by 1846 , and such establishments were mainly owned and operated by Western photographers. Western photographers active in China often employed Chinese assistants, who eventually went on to open their own studios. However, the first Chinese Studio did not appear until the opening of Ren Qingtai's celebrated Fengtai studio in 1892. From this point on, the history of photography in China belongs primarily to the Chinese. ${ }^{19}$

Actually, I have been doing research on the $19^{\text {th }}$ century Chinese photography since I started my PPCM program. In the first year of my studies, I published a joint project (with fellow student Erin Cral) on the PPCM website at:

http://www.imagearts.ryerson.ca/ppem/Other\%20Class\%20Projects/CHINA/19th\%20cent\%20China-Webpage.htm

However, we were not allowed to present the images on the website because of copyright issues. For the same reason, today I can find only a limited number of published images of China in books, and few on websites. Because these important images are often preserved in countries other than China, most Chinese people have little or no opportunity to see them. Therefore, the most significant accomplishment of my thesis project is to offer 73 images of these historic treasures to a global audience.

The research on this album is just a start, but I hope it offers a foundation for other researchers to build upon in the future. My wish is that this project will provide a

\footnotetext{
${ }^{17}$ Rosenblum, Naomi. A World History of Photography, 124. New York: Abbeville Press, 1997.

18 Ibid, 73.

${ }^{19}$ Phillips, Christopher and Vanessa Rocco. China and the Chinese in Early Photographs, 5-8. The seventh exhibition in the series "New Histories of Photography". New York: International Center of Photography, June 11-September 5, 2002; Rochester: George Eastman House, December 2-February 6, 2005.
} 
reference for others conducting research in this field. The realization of this project explores a specific way to present an album using TMS and eMuseum technologies, and can offer a reference for people who want to employ these technologies to publish other albums online. 


\section{Bibliography}

Beijing Xi Cheng Qu Archives. "Da Gao Xuan Dian Temple”. Xi Cheng Qu Archives online. $<$ http://xchda.bjma.org.cn/xcbk/gims-simiao-1.htm $>$ (15 July 2006)

Cameron, Nigel. The Face of China as Seen by Photographers \& Travelers, 1860-1912. Millerton: Aperture, 1978.

Frisch-Ripley, Karen. Unlocking the Secrets in old photographs. Salt Lake: Ancestry, 1991.

Gallery Systems. Company. $<$ http://www.gallerysystems.com/company/company.html $>$ (6 July 2006)

Gallery Systems. eMuseum3.5 Manual.

Gallery Systems. The Museum System User's Guide.

Island Blue Print. "BFK Rives Paper". IslandBlue Art Supplies Save Your Best Ideas for Us. $<$ http://www.islandblue.com/catalogue.cfm?main id =3\&sub id=14\&product id=873> $>$ (9 July 2006)

Museum Registration Materials for Fred S. Lightfoot.

New York Public Library. "Detail ID 114263”. NYPL Digital Gallery. $<$ http://digitalgallery.nypl.org/nypldigital/dgkeysearchdetail.cfm?trg=1\&strucID=138861 \&imageID $=114263 \&$ word $=\mathrm{W} \% 2 \mathrm{E} \% 20$ saunders\&s $=1$ \&notword $=\& \mathrm{~d}=\& \mathrm{c}=\& \mathrm{f}=\& 1$ Word $=$ $\underline{\& l \text { Field }=\& \text { sScope }=\& \text { sLevel }=\& \text { sLabel }=\& \text { total }=2 \& \text { num }=0 \& \text { imgs }=12 \& p \text { Num }=\& p o s=1>1}$ 4 July 2006)

Old Beijing net. "Pai-lou". Old Beijing Civilisation. $<$ http://www.obj.org.cn/article/Article Show.asp?ArticleID $=7186>(15$ July 2006)

Phillips, Christopher and Vanessa Rocco. China and the Chinese in Early Photographs. The seventh exhibition in the series "New Histories of Photography". New York: International Center of Photography, June 11-September 5, 2002; Rochester: George Eastman House, December 2-February 6, 2005.

Rosenblum, Naomi. A World History of Photography. New York: Abbeville Press, 1997.

Thomson, John. China: the Land and Its People. Hong Kong: John Warner Publications, 1977.

Thomson, John. China and Its People in Early Photographs, an Unabridged Reprint of the Classic 1873/1874 Work. New York: Dover Publications, Inc., 1982.

White, Stephen. John Thomson: A Window to the Orient. New York: Thames and Hudson, 1986. 
Xin Hua Net. "Beijing Pai-lou Titles". Xin Hua Net Beijing News.

$<$ http://www.bj.xinhuanet.com/bjpd sdwm/2006-07/05/content 6557322.htm > (15 July 2006) 